\title{
Request Strategies in Professional E-mail Correspondence: Insights from the United States Workplace
}

Lisa Leopold

Despite growing interest in the rhetorical features of e-mail correspondence, this is the first study to examine the request strategies in e-mails written by native English-speaking professionals from a variety of industries in the United States. This study uses Blum-Kulka, House, and Kasper's (1989) speech act framework to analyze the request strategies from 450 request head acts. Though often mitigated with lexico-syntactic devices, direct requests occurred at about two and one half times the rate of indirect requests, and there was some variation in request strategy according to request category, gender, status, and social distance. Although the imperative was used most frequently across all gender, status, and social distance groups, senders did not choose it - the most direct strategy-as often with recipients to whom they wrote direct requests most frequently. This shows that senders may prefer particular direct or indirect strategies over others with certain recipients. Moreover, senders often used more mitigators with recipients to whom they more frequently wrote direct requests, thus suggesting that the politeness of a request cannot be judged solely by the request strategy chosen. As the first corpus-based study that examines authentic request e-mails in the North American workplace, this study offers important pedagogical implications for professional e-mail composition.

Malgré un intérêt croissant pour les fonctions rhétoriques de la correspondance par courrier électronique, cette étude est la première à porter sur les stratégies visant les demandes dans les courriels rédigés par des professionnels d'anglais langue maternelle provenant de diverses industries aux États-Unis. Cette étude s'appuie sur le cadre portant sur les actes de langage de Blum-Kulka, House et Kasper (1989) pour analyser les stratégies qui sous-tendent 450 demandes. Bien que souvent mitigées par des mécanismes lexico-syntaxiques, les demandes directes se sont produites 2 fois et demie plus souvent que les demandes indirectes. Les stratégies variaient en fonction de la catégorie de demande, le genre, le statut et la distance sociale. Alors que l'impératif était employé le plus souvent par l'ensemble des groupes (genre, statut, distance), les expéditeurs ne se sont pas servis de cette stratégie - la plus directe - aussi souvent avec les destinataires à qui ils écrivaient des demandes directes le plus souvent. Ce résultat indique que les expéditeurs pourraient préférer certaines stratégies directes ou indirectes 
avec certains destinataires. De plus, les expéditeurs employaient souvent plus d'éléments atténuateurs avec les destinataires à qui ils envoyaient plus souvent des demandes directes, indiquant que le niveau de politesse d'une demande ne s'évalue pas uniquement selon le choix de stratégie de demande. En tant que première étude reposant sur un corpus qui porte sur des messages électroniques authentiques visant des demandes dans les milieux de travail en Amérique du Nord, ce travail offre des implications pédagogiques importantes pour la rédaction de messages électroniques professionnels.

By 2019, the number of business e-mails sent and received per day worldwide is expected to reach over 128 billion, an increase from over 112 billion in 2015 (Radicati Group, 2015). Depending on the position an employee holds within a particular company, Hong Kong professionals receive as many as 400-500 e-mails in a single day (Evans, 2012). E-mail allows users to communicate quickly across geographic and time zones, making it the dominant form of internal and external business communication (Hewitt, 2006). As business becomes more international, the frequency with which native and non-native speakers correspond via e-mail will continue to grow. Moreover, this e-mail communication is likely to be in English, the "common language" (Poncini, 2004) and "lingua franca" (Evans, 2013) of international business. Kankaanranta and Planken (2010) reported that their interviewees from western European multinational corporations used English more than their respective native languages in e-mail and other written communication, and Evans (2013) found that e-mail is already occupying the central role in Englishbased written communication among professionals in Hong Kong's service industries. Such communication requires competence in English as a lingua franca in business contexts (BELF; Kankaanranta \& Louhiala-Salminen, 2010), and it may present linguistic and cultural challenges for non-native speakers (Rogerson-Revell, 2007).

Non-native speakers may find it challenging to compose e-mails to their native English-speaking colleagues because little consensus exists whether e-mail resembles oral or written discourse. Some studies have concluded that the language of e-mail is highly informal, thus more closely resembling oral discourse (cf. Crystal, 2001; Gimenez, 2000). However, Gains (1999) found that while e-mail correspondence within a university insurance company in the United Kingdom incorporated some conversational features, the e-mail within a commercial insurance company reflected the norms of standard written English. More recently, Giménez-Moreno (2011) found register variation to be common within a single e-mail message, and Evans (2012) found that internal e-mail messages were much less formal than external e-mail messages. Therefore, it has been questioned whether "a language of e-mail" exists, because of the diversity of purposes and contexts in which e-mail is used (Androutsopoulos, 2006, p. 420). 
Composing e-mails for different purposes, particularly for those involving face-threatening acts, requires a sophisticated command of pragmatics, which may be difficult for even advanced learners of English (cf. Bodman \& Eisenstein, 1988). Studies show that employees feel uneasy about writing e-mails involving requests and other face-threatening acts, especially when they are directed to their superiors (Baron, 2000; Kling, 1996). Many variables have been found to impact interlocutors' choice of request strategy: request goal, age of the addressee, and power of the speaker (Blum-Kulka, Danet, \& Gherson, 1985); power, social distance, and degree of imposition (Brown \& Levinson, 1987); social distance and power (Wolfson, 1989); degree of imposition (Blum-Kulka \& House, 1989); gender and status (O'Neill \& Colley, 2006); and purpose of interaction, status, social distance, and gender (Vine, 2009). Given the range of variables non-native speakers must consider when formulating requests, pragmatic errors could occur, especially because e-mail lacks the paralinguistic and tonal cues of speech.

In fact, a large body of research on the request speech act has focused on learners' ability to adopt pragmatically appropriate request strategies (cf. Fordyce \& Fukazawa, 2004; Lee, 2004) and cross-cultural comparisons of politeness and directness (cf. Blum-Kulka, 1987). Many studies have revealed differences in the way native and non-native speakers formulate requests, with higher levels of directness among Danish and German learners of English (House \& Kasper, 1987) and Japanese learners of English (Ellis, 1992), fewer internal modifiers among Australian adult learners of Indonesian (Hassall, 2001), and a general tendency of learners toward verbosity (Blum-Kulka \& Olshtain, 1986). However, all of these studies used discourse completion or role-play tasks, methods criticized for their lack of authenticity (Wolfson, Marmor, \& Jones, 1989).

Much of the existing, albeit limited, research on authentic request e-mails has compared e-mails written by native and non-native English-speaking graduate students to faculty (e.g., Biesenbach-Lucas, 2005, 2007; Chen, 2001, 2006). In these studies, differences have also emerged: native speakers used more mitigators (Hartford \& Bardovi-Harlig, 1996), more modal constructions and hedged expressions (Biesenbach-Lucas \& Weasenforth, 2000), and a greater frequency and variety of politeness strategies (Biesenbach-Lucas, 2007; Chen, 2001). Some researchers have concluded that native speakers' requests are more polite than those of non-native speakers (Biesenbach-Lucas, 2007; Chen, 2001). Taken collectively, the research reveals that non-native speakers formulate requests differently than native speakers do and must possess sensitivity to text-external variables so that their requests are not perceived as impolite.

Given the aforementioned challenges for non-native speakers, English for Specific Purposes (ESP) instructors may want to provide instruction on professional e-mail composition to help non-native speakers succeed in workplace communication. As Tatton (2008) and others have concluded, real 
data are essential for creating appropriate instructional materials. However, using data from existing research on student e-mails to professors may be problematic, as these e-mails could be quite different from the e-mails that employees write to their subordinates, colleagues, and superiors in the workplace. Yet due to privacy concerns, it is extremely difficult to collect data from the business world (Van Nus, 1999), and corpora of authentic e-mail correspondence do not exist, other than corpora of Enron e-mails (Kessler, 2010). This may be one reason for the "dearth of pedagogically oriented research into e-mail use in the field of ESP" (Evans, 2012, p. 204). In fact, most business English textbooks that address e-mail correspondence are based on the author's intuitions rather than on empirical data (cf. Mackey, 2004), but research comparing authentic oral requests with textbook examples shows that these intuitions are not always accurate (Schmidt, 1994). Although no study to date has compared authentic and textbook e-mail requests, evidence from previous studies on oral requests suggests that the gap between the author's intuitions and authentic data may be wider than most ESP instructors would anticipate. Moreover, previous studies have shown that a lack of authentic models may lead non-native-speaking graduate students to formulate their own assumptions about e-mail correspondence and guess (sometimes incorrectly) about the appropriate style and tone of e-mails to faculty (BiesenbachLucas, 2007; Chen, 2006). Therefore, corpus-based research on professional e-mail correspondence is needed to narrow the chasm that exists between ESP instruction and real-world communication (Evans, 2012).

The existing, albeit relatively scant, research on professional e-mails has focused on e-mails in corporations outside the United States, and the data are usually gathered from a single institution (sometimes from a single employee), which is not necessarily representative of e-mail correspondence in other professional settings (cf. Gains, 1999; Gimenez, 2000, 2006; GiménezMoreno, 2011; Ho, 2010). Moreover, much of the general BELF research has focused on European contexts (Ehrenreich, 2010), yet it would seem that research conducted with native speakers of English in other settings would also be important for revealing some of the "genre rules" that are so important for successful BELF communication (Kankaanranta \& Louhiala-Salminen, 2010). This line of research would provide ESP instructors with professional native speaker models, which are currently underrepresented in the ESP literature. These examples could then be presented to students as one of several (rather than the sole) models, an approach that need not be inconsistent with that advocated in the BELF literature (Kankaanranta \& Louhiala-Salminen, 2010). In fact, research on professional e-mail correspondence in the United States in particular, because it is the country with the largest economy and the largest number of international students, would certainly be informative for ESP practitioners who teach international students. Yet very few studies have reported on the textual features of professional e-mail correspondence in the United States workplace, and none has focused exclusively on request e-mail correspondence. 
This is the first study to date to investigate request strategies in e-mail correspondence across industries in the United States. The study analyzed 205 request e-mails (containing 450 head acts) from native English-speaking professionals in a broad sector of industries, such as finance, hospitality, and healthcare. The request strategies were identified using the Cross-Cultural Speech Act Realization Project (CCSARP) framework (Blum-Kulka, House, \& Kasper, 1989). From a survey completed by participants, the sender's and recipient's gender, social distance, and status were assessed to determine whether these features impacted the sender's choice of request strategy. Specifically, the research questions were:

1. What are the frequencies of direct and indirect request strategies in emails written by native English-speaking professionals in the workplace?

2. How do request strategies vary depending upon request type?

3. How do gender, social distance, and status appear to affect the sender's choice of request strategy in workplace e-mails?

\section{Material and Methods}

\section{Theoretical background to the analysis}

By adopting a social constructionist view in which genre is dependent on context (Bremner, 2006), this study aimed to deepen understanding of the formulation of the request speech act among a select group of participants within the United States workplace. Whereas other studies have tended to focus on requests in other contexts or used data from oral samples or discourse completion tasks, this study used a corpus-based approach, one of the "most powerful tools" for analyzing text (Bhatia \& Bremner, 2012). The request strategies were analyzed according to gender, social distance, and status - sociolinguistic variables chosen not only because they have been found to influence the formulation of requests (cf. Brown \& Levinson, 1987; O'Neill \& Colley, 2006; Vine, 2009), but also because they could be assessed from a survey that participants completed (unlike the imposition of a request, which might need verification from the recipient). Moreover, it was hoped that this analysis would help fulfill the need for additional research on gender differences in workplace communication (Beaufort, 2008) and on the linguistic realization of politeness in workplace communication (Bhatia \& Bremner, 2012).

Requests in this study were defined as "polite demands for something" or "a favour [asked] of the other person" (Nelson, Carson, Al Batal, \& El Bakary, 2002, p. 169), and the request head act was defined as "the nucleus of the speech act ... that part of the sequence which might serve to realize the act independently of other elements" (Blum-Kulka \& Olshtain, 1984, p. 200). An example from the corpus illustrates the difference between the head act and other elements supporting the request: "Please cc all of us on this e-mail as I'll be out at a client meeting this afternoon and I don't want to lose any time 
on this." In this example, the head act is "cc all of us on this e-mail." "Please" is one type of mitigator-a politeness feature. What follows the head act is a supportive move (grounder), according to the classification scheme developed by Blum-Kulka, House, and Kasper (1989).

\section{Participants}

Participants were native English-speaking volunteers who worked in 18 different industries and whose e-mail recipients worked in 21 different industries. According to self-report data gathered from a survey, the top three industries for senders were (a) education, (b) administration/office, and (c) business/management. The top three industries for recipients were (a) education, (b) administration/office, and (c) banking/accounting/finance. Although there is a possible overlap among industries (e.g., one could work in administration within an educational institution), participants self-selected the industry that most closely matched their profession. Participants came from regions throughout the United States, with greater numbers from the Midwest and West. They held a wide variety of entry-level (e.g., administrative assistant, legal assistant), mid-level (e.g., college counsellor, operations specialist, graphic designer), and senior level (e.g., senior vice president, owner, president) positions within their company, with the majority occupying mid- or senior-level positions. Participants ranged in age from 18 to $76+$, with the greatest number of e-mails (69) from senders aged 46-55, nearly an equivalent number from senders 36-45 and 56-65 (45 and 44, respectively), and the remainder from senders younger than 36 or older than 65 .

Table 1 shows participants' approximation of their recipients' age in comparison to their own age bracket.

Table 1

Age of E-mail Recipients

\begin{tabular}{lc}
\hline Age of Recipient & Number of E-mails \\
\hline Younger than sender & 67 \\
Older than sender & 47 \\
Same age bracket & 43 \\
Do not know age of recipient & 38 \\
Did not disclose age & 10 \\
\hline Total & 205 \\
\hline
\end{tabular}

The gender of senders and recipients is shown in Table 2. Males wrote 76 of the request e-mails, and females wrote 129. 
Table 2

Gender of E-mail Senders and Recipients

\begin{tabular}{lcc}
\hline Gender & Number of E-mails & Number of Head Acts \\
\hline Male sender and male recipient & 41 & 99 \\
Male sender and female recipient & 32 & 69 \\
$\begin{array}{l}\text { Male sender and unknown/unstated gender of } \\
\text { recipient }\end{array}$ & 3 & 6 \\
$\begin{array}{l}\text { Female sender and female recipient } \\
\text { Female sender and male recipient }\end{array}$ & 64 & 125 \\
$\begin{array}{l}\text { Female sender and unknown/unstated gender of } \\
\text { recipient }\end{array}$ & 56 & 131 \\
\hline Total & 205 & 20 \\
\hline
\end{tabular}

\section{Procedure}

A colleague and I e-mailed a link to an online survey to all the native English-speaking professionals we knew. To recruit the most participants, we used snowball sampling by asking these professionals to forward the survey to professionals they knew. The survey asked participants to submit one well-written, professional e-mail they had written to an individual, such as a superior, subordinate, colleague, client, or vendor, with all identifying information removed. Participants were then requested to answer questions about the e-mail they submitted, and they were allowed to complete the survey more than once with different e-mails.

\section{Analysis}

From the 249 professional e-mails collected between July and December 2011, the sample was narrowed to 210 that contained at least one request head act. Four of the 210 e-mails were eliminated from the analysis due to insufficient survey data, and one e-mail was eliminated because it contained more than 20 head acts, which would have skewed the final analysis. Thus, the sample was narrowed to 205 request e-mails written by native English speakers.

The original CCSARP framework developed by Blum-Kulka et al. (1989) was used to manually identify 450 head acts from the 205 request e-mails and to classify the request strategy. Following Biesenbach-Lucas's (2007) study of students' written requests to faculty, need and expectation statements were classified as direct strategies. Query and stating preparatory strategies were separated, and mild and strong hints were collapsed into one category. A frequency count was conducted of all the request strategies according to request category, gender, social distance, and status, and the classification scheme was separately analyzed three times. 
The request strategies were then classified as direct, conventionally indirect, or non-conventionally indirect, as shown in Table 3.

Table 3

Classification of Request Strategies

\begin{tabular}{|c|c|c|}
\hline Directness Level & Request Strategy & Example from Dataset \\
\hline Direct & Imperative & $\begin{array}{l}\text { Please give me a call at your earliest con- } \\
\text { venience and we can discuss this in more } \\
\text { detail. }\end{array}$ \\
\hline Direct & Elliptical & It is leaking $\ldots$ any suggestions?? \\
\hline Direct & Explicit performative & $\begin{array}{l}\text { I am requesting Monday, July } 11 \text { th as a vaca- } \\
\text { tion day. }\end{array}$ \\
\hline Direct & Hedged performative & $\begin{array}{l}\text { I must again ask if there is any way at all that } \\
\text { in-person meetings could be held on week- } \\
\text { day mornings rather than evenings. }\end{array}$ \\
\hline Direct & Direct question & $\begin{array}{l}\text { How does your department handle the pre- } \\
\text { requisite issue? }\end{array}$ \\
\hline Direct & Locution derivable & $\begin{array}{l}\text { p.s. if you want a damn good car at a damn } \\
\text { good price, well then you'd better damn well } \\
\text { come and see me! }\end{array}$ \\
\hline Direct & Want statement & $\begin{array}{l}\text { I would really like to have a discussion } \\
\text { concerning the specific Zone numbers and } \\
\text { dilemma. }\end{array}$ \\
\hline Direct & Need statement & $\begin{array}{l}\text { I need at least } 3 \text { (preferably more) com- } \\
\text { parable sales of duplexes prior to } 3 / 31 / 11 \text {, } \\
\text { including the following information for each: } \\
\text { address, square footage, year built, \# of } \\
\text { baths/br's, rental income, proximity to my } \\
\text { property. }\end{array}$ \\
\hline Direct & Suggestory & Finally, let's chat about the scores. \\
\hline Direct & $\begin{array}{l}\text { Expectation } \\
\text { statement }\end{array}$ & $\begin{array}{l}\text { I'm hoping that maybe you could fill me in on } \\
\text { anything I might have missed ... an agree- } \\
\text { ment of some sort or if maybe they'd be will- } \\
\text { ing to train? }\end{array}$ \\
\hline Conventionally indirect & Query preparatory & Could you process this course request? \\
\hline Conventionally indirect & Stating preparatory & $\begin{array}{l}\text { I would appreciate if you could communicate } \\
\text { this to the committee. }\end{array}$ \\
\hline $\begin{array}{l}\text { Non-conventionally } \\
\text { indirect }\end{array}$ & Hint & $\begin{array}{l}\text { Once you sign the letter and return it along } \\
\text { with the deposit payment, we can get started } \\
\text { promptly. }\end{array}$ \\
\hline
\end{tabular}

Searle (1976) identified a variety of request types, including those for information, goods and services, and permission. In this study, the following request types and examples emerged from my dataset and are illustrated in Table 4. 
Table 4

Request Types

\begin{tabular}{|c|c|c|c|}
\hline $\begin{array}{l}\text { Request } \\
\text { Type }\end{array}$ & $\begin{array}{c}\text { Number in } \\
\text { Dataset }\end{array}$ & Definition & Example from Dataset \\
\hline $\begin{array}{l}\text { Request for } \\
\text { information }\end{array}$ & 160 & $\begin{array}{l}\text { The writer requests information from } \\
\text { the recipient, which includes, but } \\
\text { is not limited to, facts, instructions, } \\
\text { explanations, or the recipient's } \\
\text { preferences. }\end{array}$ & $\begin{array}{l}\text { How do I get a rate on } \\
\text { your website? }\end{array}$ \\
\hline $\begin{array}{l}\text { Request for } \\
\text { action }\end{array}$ & 129 & $\begin{array}{l}\text { The writer requests the recipient to take } \\
\text { action, which includes, but is not limited } \\
\text { to, sending a document, deposit, or } \\
\text { donation; completing an application or } \\
\text { questionnaire; signing a letter; sharing } \\
\text { a link; calling; solving a problem; or } \\
\text { considering a proposal. }\end{array}$ & $\begin{array}{l}\text { I would like to request } \\
\text { that two (2) certified } \\
\text { copies of the death } \\
\text { certificate for [FIRST } \\
\text { NAME LAST NAME] } \\
\text { be sent to [FUNERAL } \\
\text { HOME] at the below } \\
\text { listed address. }\end{array}$ \\
\hline $\begin{array}{l}\text { Request for } \\
\text { continued } \\
\text { correspon- } \\
\text { dence }\end{array}$ & 42 & $\begin{array}{l}\text { The writer asks the recipient to be kept } \\
\text { informed or to provide notification should } \\
\text { the recipient have any questions or need } \\
\text { any help. }\end{array}$ & $\begin{array}{l}\text { Let me know if you } \\
\text { have any questions. }\end{array}$ \\
\hline $\begin{array}{l}\text { Request for } \\
\text { meeting }\end{array}$ & 39 & $\begin{array}{l}\text { The writer either states a desire to meet } \\
\text { with the recipient or inquires about } \\
\text { the availability and willingness of the } \\
\text { recipient to meet. }\end{array}$ & $\begin{array}{l}\text { Was checking to see } \\
\text { if you had time for a } \\
\text { quick stop by and see } \\
\text { what we do and meet } \\
\text { our people? }\end{array}$ \\
\hline $\begin{array}{l}\text { Request for } \\
\text { permission }\end{array}$ & 32 & $\begin{array}{l}\text { The writer seeks the recipient's approval } \\
\text { or inquires whether an action would be } \\
\text { possible. }\end{array}$ & $\begin{array}{l}\text { May I have your } \\
\text { permission to add } \\
\$ 50 \text { to the cost of } \\
\text { texts ( } \$ 25 / \text { student) for } \\
\text { [FIRST NAME] and } \\
\text { [FIRST NAME]? }\end{array}$ \\
\hline $\begin{array}{l}\text { Request for } \\
\text { confirmation }\end{array}$ & 20 & $\begin{array}{l}\text { The writer seeks the recipient's } \\
\text { verification as to whether (a) the writer } \\
\text { and the recipient are in agreement; (b) } \\
\text { the writer's understanding is correct; } \\
\text { (c) the recipient accepts the terms } \\
\text { of a contract; or (d) the recipient has } \\
\text { received something. }\end{array}$ & $\begin{array}{l}\text { So, that means I'm still } \\
\text { looking for at least } 230 \\
\text { words to cut, right? }\end{array}$ \\
\hline $\begin{array}{l}\text { Request for } \\
\text { advice }\end{array}$ & 17 & $\begin{array}{l}\text { The writer asks for the recipient's input } \\
\text { to inform a decision that will be made. }\end{array}$ & $\begin{array}{l}\text { What would you } \\
\text { recommend? }\end{array}$ \\
\hline $\begin{array}{l}\text { Request for } \\
\text { feedback }\end{array}$ & 11 & $\begin{array}{l}\text { The writer either expresses a desire for } \\
\text { the recipient's feedback on a document } \\
\text { or solicits input on a decision that has } \\
\text { already been made. }\end{array}$ & $\begin{array}{l}\text { Would you review the } \\
\text { attached and provide } \\
\text { me some feedback on } \\
\text { the medical personnel } \\
\text { that satisfy these } \\
\text { requirements? }\end{array}$ \\
\hline
\end{tabular}




\section{Results}

This section first examines the frequency of direct and indirect request strategies in the dataset and then analyzes this frequency according to request category, gender, social distance, and status.

\section{Frequency of direct and indirect request strategies}

Among the 450 head acts, 322 (71.55\%) were direct, 113 (25.11\%) were conventionally indirect, and 15 (3.33\%) were non-conventionally indirect. Table 5 shows the frequency of request strategies in the dataset. The predominance of direct requests may be partially attributed to the fact that there are many more direct than indirect request categories. However, future studies using different e-mail corpora from the U.S. workplace may reveal whether direct request strategies are generally preferred over indirect request strategies in e-mail correspondence in the U.S. workplace.

\section{Table 5}

Frequency of Request Strategies

\begin{tabular}{llc}
\hline Directness Level & Request Strategy & Number of Head Acts \\
\hline Direct & Imperative & 155 \\
Direct & Elliptical & 19 \\
Direct & Explicit performative & 14 \\
Direct & Hedged performative & 12 \\
Direct & Direct question & 57 \\
Direct & Locution derivable & 4 \\
Direct & Want statement & 27 \\
Direct & Need statement & 16 \\
Direct & Suggestory & 6 \\
Direct & Expectation statement & 12 \\
Conventionally indirect & Query preparatory & 81 \\
Conventionally indirect & Stating preparatory & 32 \\
Non-conventionally indirect & Hint & 15 \\
\hline Total & & 450 \\
\hline
\end{tabular}

As Table 5 shows, the most frequently used strategy was the most direct strategy-the imperative. Although the predominance of the imperative in the 
dataset was initially surprising, closer examination revealed that the imperative requests were not always as direct as the strategy seemed to suggest. In fact, among the 155 imperatives, 105 were mitigated with "please," as shown in this example from the dataset: "Please send the check using the enclosed self-addressed stamped envelope by November 10, 2011." Additionally, five were mitigated with "just" (e.g., "Just let me know when you would like to speak.") While many verbs were used to make imperative requests, 67 of the 155 imperative requests contained the verb "let," which appeared to soften the request, as these examples from dataset show: "Please let FIRST NAME know that he can now use that conference room for his mediation" and "So, for your return shipping check, I can either mail it back to you, or just shred it, so let me know which you prefer." No other verb occurred with such frequency among the imperative requests; in fact, the next most popular verbs ("advise" and "send") appeared only nine and eight times, respectively. Moreover, some imperative requests appeared to suggest a reader benefit more than an imposition, as these examples from the dataset seem to suggest, "Respond to this e-mail with your full mailing address and an exam copy will be sent to you as soon as possible" and "... then just let me know if okay or if I can help in any other way." Although the imperative is considered the most direct strategy, many of the imperatives in this corpus were softened.

Senders also relied on mitigators to soften other direct requests. In fact, every occurrence of "want" in the 27 want statements was mitigated. Senders used the conditional form "would like" most frequently on 11 occasions, followed by the conditional "would love" on 8 occasions and the past tense "wanted" on 5 occasions. Examples from the dataset include, "I'd love to chat with you this week or next to hear more about your interest" and "I understand from our meeting this past March that you intend to do the same this year; however, I just wanted to check-in about it since I am currently mapping out the upcoming year." When mitigated, this direct request strategy appears to be polite. Native English speakers never formed a declarative sentence with the present tense verb "want," which is an important consideration for ESP instructors and their learners to know. Yet mitigation was not as commonly used with the "need" request strategy, where 11 of the 16 requests using this strategy were unmitigated, as this action request to a vendor illustrates: "We also need a new draft contract for discussion during this conference call." Perhaps there is a difference between formulating requests to express one's needs and those to express one's desires: senders may feel justified expressing their needs directly without softening them, but they may prefer to express their desires using mitigated want strategies.

With regard to the 14 explicit performative requests, senders used the verb "writing" on 5 occasions (and 4 of these 5 were directed to a peer at a different institution), as this example from the dataset shows: "I'm writing to see if you're interested in participating in the XXX conference as you have in the past couple years." The verb "requesting" was used in 4 explicit perfor- 
mative requests, all of which were directed to superiors, as this example from the dataset shows: "I am requesting 4 vacation days in Sept. $(12,13,14,15) . "$

With regard to the 12 hedged performative requests in the dataset, 3 were formed with the expression "would like to request" as this example from the dataset shows: "I would like to request a couple of tables and a couple of trash cans for the event and was hoping you were the right person to contact." An additional 2 hedged performative requests were formed with each of the following expressions: "wanted to check in," "wanted to ask," and "would like to ask."

Two thirds (4 of 6) of the suggestory requests used "let's" as this example from the dataset shows: "Let's make a time," a construction that would appear to minimize the imposition on the receiver.

However, direct strategies were not always preferred. The query preparatory was the second most popular strategy with 81 occurrences. This is not particularly surprising, considering that other researchers have highlighted the query preparatory as a preferred strategy in graduate student e-mails to faculty (Chen, 2001) and in discourse completion tasks (Lee, 2004). Query preparatory questions were most commonly formed with "would," followed by an equivalent number with "could" and "can."

\section{Request strategies according to request category}

The percentage of request strategies according to request category is presented in Table 6. For all request categories, the percentage of direct request strategies exceeded the percentage of indirect request strategies. The greatest percentage of direct requests was for continued correspondence, and the greatest percentage of indirect requests was for permission.

When making requests for action, confirmation, and continued correspondence, writers most often used imperatives. Examples from the dataset include "Please share this with the team" (for action), "Please let me know if we agree" (for confirmation), and "Let me know" (for continued correspondence). In fact, the imperative was used in more than $78 \%$ of requests for continued correspondence, largely because the structure "let me know" was so common, even in longer requests for continued correspondence, as this example illustrates: "If you do find the bins down there please let me know and I will remind them again to bring the bins back upstairs." A limited range of request strategies was used in requests for continued correspondence and confirmation; in fact, continued correspondence represented the only request category that was never formulated with a complete grammatical interrogative (i.e., either the direct question or query preparatory). Among the 55 imperative action requests in the dataset, 46 were mitigated (40 with "please") as this example shows: "Please let [first name] know that he can now use that conference room for his mediation." Among the 9 unmitigated action requests, 7 appeared as items in a list, including this one: "Call the mortgage company and tell them NOT 
to pay the AAA bill, but to pay the Badger one instead." Thus, unmitigated imperative action requests that did not appear as an item in a list were very rare in the dataset.

Table 6

Percentage of Request Strategies by Request Category

\begin{tabular}{|c|c|c|c|c|c|c|c|c|}
\hline $\begin{array}{l}\text { Request } \\
\text { Category }\end{array}$ & $\begin{array}{r}\text { Informa- } \\
\text { tion }\end{array}$ & Action & $\begin{array}{r}\text { Continued } \\
\text { Corres- } \\
\text { pondence }\end{array}$ & $\begin{array}{r}\text { Meet- } \\
\text { ing }\end{array}$ & $\begin{array}{r}\text { Per- } \\
\text { mission }\end{array}$ & $\begin{array}{r}\text { Confirm- } \\
\text { ation }\end{array}$ & Advice & $\begin{array}{l}\text { Feed- } \\
\text { back }\end{array}$ \\
\hline Imperative & 25.0 & 42.64 & 78.57 & 20.51 & 18.75 & 35.00 & 23.53 & 18.18 \\
\hline Elliptical & 8.75 & 0.78 & 0 & 0 & 3.13 & 0 & 11.76 & 9.09 \\
\hline $\begin{array}{l}\text { Explicit } \\
\text { performative }\end{array}$ & 3.13 & 2.33 & 0 & 2.56 & 12.50 & 0 & 0 & 9.09 \\
\hline $\begin{array}{l}\text { Hedged } \\
\text { performative }\end{array}$ & 2.50 & 3.88 & 0 & 2.56 & 6.25 & 0 & 0 & 0 \\
\hline $\begin{array}{l}\text { Direct } \\
\text { question }\end{array}$ & 25.63 & 0 & 0 & 10.26 & 3.13 & 15.00 & 41.18 & 9.09 \\
\hline $\begin{array}{l}\text { Locution } \\
\text { derivable }\end{array}$ & 0.63 & 2.33 & 0 & 0 & 0 & 0 & 0 & 0 \\
\hline $\begin{array}{l}\text { Want } \\
\text { statement }\end{array}$ & 1.25 & 4.65 & 9.52 & 15.38 & 9.38 & 25.00 & 0 & 9.09 \\
\hline $\begin{array}{l}\text { Need } \\
\text { statement }\end{array}$ & 3.13 & 6.98 & 2.38 & 2.56 & 0 & 0 & 0 & 0 \\
\hline Suggestory & 0 & 2.33 & 2.38 & 2.56 & 0 & 5.00 & 0 & 0 \\
\hline Expectation & 1.25 & 6.20 & 0 & 5.13 & 0 & 0 & 0 & 0 \\
\hline Total direct & 71.25 & 72.09 & 92.86 & 61.54 & 53.13 & 80.00 & 76.47 & 54.55 \\
\hline $\begin{array}{l}\text { Query } \\
\text { preparatory }\end{array}$ & 18.75 & 15.50 & 0 & 28.21 & 34.38 & 20.00 & 17.65 & 18.18 \\
\hline $\begin{array}{l}\text { Stating } \\
\text { preparatory }\end{array}$ & 7.50 & 6.98 & 4.76 & 7.69 & 12.50 & 0 & 5.88 & 9.09 \\
\hline Hint & 2.50 & 5.43 & 2.38 & 2.56 & 0 & 0 & 0 & 18.18 \\
\hline Total indirect & 28.75 & 27.91 & 7.14 & 38.46 & 46.88 & 20.00 & 23.53 & 45.45 \\
\hline
\end{tabular}

Information and advice requests were most frequently made with direct questions, as these examples illustrate: "How does your department handle the prerequisite issue?" (for information) and "What would you recommend?" (for advice). One could argue that simple requests for information 
and advice may not pose a great imposition to the recipient, and perhaps this is one reason why direct questions were considered an appropriate strategy for posing these types of requests. Although senders used a wide variety of request strategies for formulating information requests (all but the suggestory), they used a limited number of strategies for formulating advice requests: the explicit performative, hedged performative, locution derivable, want statement, need statement, suggestory, expectation, and hint strategies were never used. Considering that 10 of the 17 requests for advice were formulated using either the direct question or query preparatory, it might be more common for senders to use a question than a declarative statement when requesting advice.

Requests for meetings and permission were most often made with the query preparatory strategy, as these examples illustrate: "Would we be able to schedule an appointment to talk on Skype or by phone?" (for meeting) and "Would it be possible for me to receive a one-week extension on the deadline, and to submit my manuscript by August 22nd, at the latest?" (for permission). In general, requests for permission were often formulated with indirect strategies (either the query or stating preparatory), with those two categories accounting for nearly half of the total requests for permission. When requests for permission were made with direct strategies, they were almost always mitigated. For example, all six requests for permission using the imperative included the politeness marker "please," as this example from the dataset shows: "Please let me know if this would be all right." Requests for permission were never made with the locution derivable, need statement, suggestory, expectation, or hint statements, as such formulations might have seemed either too brash or ambiguous when seeking permission.

Some request strategies were used much more frequently with certain request categories. For example, 14 of the 19 elliptical requests in the dataset were for information and 41 of the 57 direct questions were for information. Eight of the 12 expectation statements were for action; 7 of the 15 hints were for action. This shows that senders may have distinct preferences for the strategies they use to formulate certain types of requests.

\section{Request strategies according to gender}

The request strategies males and females adopted when writing requests to both genders are shown in Table 7 as a percentage of the total head acts written by that gender cohort. As a whole, males used more direct strategies and fewer conventionally indirect strategies than females. This is despite the fact that males wrote a lesser percentage of requests for action, confirmation, and continued correspondence, and a greater percentage of requests for meetings and permission than females did, which suggests that request type was not likely a confounding variable.

Across gender groups, the most popular request strategy was the imperative. Whereas females used nearly the same percentage of imperatives when 
addressing males and females, males used about $10 \%$ more imperatives when addressing females than they did males. Males used direct questions just as frequently as imperatives when writing requests to other males and more frequently than when they were writing requests to females. In fact, imperatives and direct questions accounted for more than $50 \%$ of the strategies males used when writing requests to other males. Females tended to use more want and need statements, query preparatory, and stating preparatory strategies, and fewer direct questions than males did when making requests. However, whereas females used more want statements when addressing males, they used more need statements when addressing females. If one were to compare the direct question and the query preparatory (the only two categories involving a complete, grammatical interrogative), the fact that males favored direct questions and females preferred query preparatory strategies might be an indicator of males' tendency to adopt a more direct style of communication than females, and indeed the data did show that males adopted a greater percentage of direct strategies overall as compared to females. However, this does not mean that males always used a greater percentage of direct request strategies than females for all request types. Notably, 11 of the 13 requests for permission from males were indirect, whereas only 4 of the 19 requests for permission from females were indirect. When making requests for permission, females preferred the imperative structure as this example from the dataset shows, "Please advise if I may change my vacation day from Mon., July 11th to Thurs., July 7th," whereas males preferred the query preparatory strategy, as in this example from the dataset: "Would you be OK with this option?"

Gender appeared to affect not only the request strategy senders adopted but also the manner in which they formulated the request. In fact, females used "would" most frequently in their query preparatory requests (in $27.78 \%$ of cases), nearly twice the percentage with which males used "would" ( $14.81 \%$ of cases). By contrast, males used "can" most frequently to formulate query preparatory requests (in $37.04 \%$ of cases). The comparison is notable, considering that "would" is a mitigated form (the past tense of "will") and "can" is an unmitigated form. This would seem to indicate that even when formulating indirect requests, males seemed to favor a more direct approach than females did.

As a whole, the greatest percentage of mitigated requests was from female senders to male recipients $(74.81 \%)$, and the smallest percentage of mitigated requests was from male senders to male recipients (52.53\%). Males also wrote the greatest percentage of requests containing no mitigators or intensifiers when writing to other males $(40.4 \%)$. Both males and females mitigated over $10 \%$ more requests when writing to recipients of the opposite gender, which may mean that they adopt a less direct communication style when writing to them. The analysis of request strategies, mitigators, and intensifiers suggests that males tend to craft more direct e-mail requests than females do. 


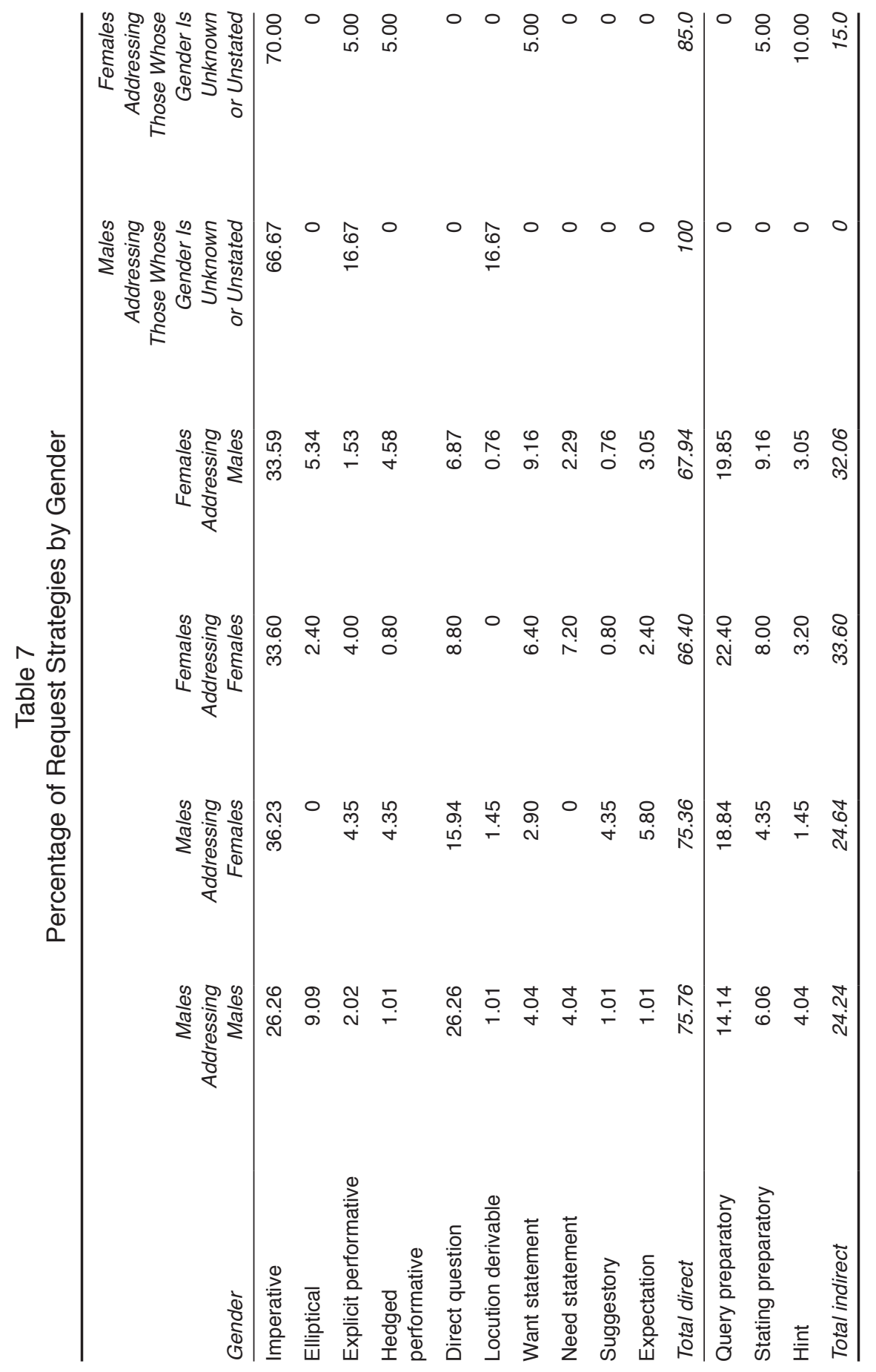




\section{Request strategies according to social distance}

The strategies senders adopted when writing requests to recipients with varying degrees of social distance are shown in Table 8, as a percentage of the total head acts written by that cohort. Thirty-one head acts were directed to those with whom the sender had a close relationship; 118 to those with whom the sender had a friendly and professional relationship; 110 to those with whom the sender had a professional relationship; 86 to those with whom the sender had a professional and formal relationship; and 105 to recipients the sender did not know. Senders used direct strategies most frequently when writing to recipients with whom they had a professional and formal relationship and least frequently when writing to recipients with whom they had a close relationship. This is despite the fact that senders wrote the smallest percentage of requests for continued correspondence to recipients with whom they had a professional and formal relationship, and they wrote the second or third highest percentage of requests for all other request categories to these recipients. Moreover, senders wrote the greatest percentage of requests for action and continued correspondence and the lowest percentage of requests for permission to close recipients, which suggests that request type was not likely a confounding variable. The relationship between social distance and directness suggests that, at least in terms of request strategy, senders may prefer a more direct communication style with recipients with whom they have a professional and formal relationship and a less direct style with those with whom they have a close relationship. This is inconsistent with previous research, which suggests that greater social distance between interlocutors corresponds with a less direct communication style (Brown \& Levinson, 1987). This finding should be interpreted cautiously, however, because females did write $81 \%$ of the requests to close recipients, suggesting that gender may have affected these results. Yet the percentage of e-mails written by females in the professional and formal category was also 14 percentage points higher than the percentage written by males, which would seem to moderate this effect somewhat.

Although senders used indirect request strategies most frequently with close recipients, it should also be noted that senders were least likely to mitigate and most likely to intensify requests to recipients with whom they had a close relationship as compared to other social distance categories. It could be that senders' preference for direct or indirect strategies should not be judged solely by the request strategy chosen, but also by the presence or absence of mitigators contained therein.

Across all social distance categories, the imperative was the most popular strategy senders used to make requests. However, considering that senders used the greatest percentage of direct requests with recipients with whom they had a professional and formal relationship, it is surprising that they used the smallest percentage of imperatives with this group. One of the primary 
reasons for the frequency of direct strategies with the professional and formal category appears to lie not with the imperative but rather with the senders' choice of interrogative strategy: senders used direct questions somewhat frequently $(18.60 \%)$ when they had a professional and formal relationship with the recipient, but very infrequently $(3.23 \%)$ when they had a close relationship with the recipient. In fact, it was only to recipients in the professional and formal category that the number of direct questions exceeded that of the query preparatory strategy, as the query preparatory was the next preferred strategy after the imperative for recipients in all other social distance categories. Senders used query preparatory strategies more frequently $(22.58 \%)$ with close recipients, but less frequently $(12.79 \%)$ with those with whom they

\section{Table 8}

Percentage of Request Strategies by Social Distance

\begin{tabular}{|c|c|c|c|c|c|}
\hline Social Distance & Close & $\begin{array}{l}\text { Friendly but } \\
\text { Professional }\end{array}$ & Professional & $\begin{array}{r}\text { Professional } \\
\text { and Formal }\end{array}$ & $\begin{array}{r}\text { Don't Know } \\
\text { Recipient }\end{array}$ \\
\hline Imperative & 32.26 & 36.44 & 37.27 & 31.40 & 32.38 \\
\hline Elliptical & 0 & 1.69 & 2.70 & 9.30 & 5.71 \\
\hline $\begin{array}{l}\text { Explicit } \\
\text { performative }\end{array}$ & 3.23 & 0.85 & 5.45 & 2.33 & 3.81 \\
\hline $\begin{array}{l}\text { Hedged } \\
\text { performative }\end{array}$ & 3.23 & 1.69 & 1.82 & 3.49 & 3.81 \\
\hline Direct question & 3.23 & 17.80 & 9.09 & 18.60 & 8.57 \\
\hline $\begin{array}{l}\text { Locution } \\
\text { derivable }\end{array}$ & 3.23 & 1.69 & 0 & 0 & 0.95 \\
\hline Want statement & 9.68 & 3.39 & 7.27 & 4.65 & 7.62 \\
\hline Need statement & 9.68 & 5.08 & 0.91 & 4.65 & 1.90 \\
\hline Suggestory & 0 & 0.85 & 0.91 & 1.16 & 2.86 \\
\hline Expectation & 0 & 2.54 & 4.55 & 3.49 & 0.95 \\
\hline Total direct & 64.52 & 72.03 & 70.0 & 79.07 & 68.57 \\
\hline $\begin{array}{l}\text { Query } \\
\text { preparatory }\end{array}$ & 22.58 & 19.49 & 20.00 & 12.79 & 17.14 \\
\hline $\begin{array}{l}\text { Stating } \\
\text { preparatory }\end{array}$ & 9.68 & 5.08 & 5.45 & 6.98 & 10.48 \\
\hline Hint & 3.23 & 3.39 & 4.55 & 1.16 & 3.81 \\
\hline Total indirect & 35.48 & 27.97 & 30.0 & 20.93 & 31.43 \\
\hline
\end{tabular}


had a professional and formal relationship. Interestingly, females writing to recipients close to them and to those with whom they had a professional and formal relationship used an equivalent number of direct questions (1 of 20) and query preparatory strategies (7 of 54) for each social distance category, suggesting no interaction between gender and social distance (when analyzing data from females). However, males never chose the direct question or the query preparatory strategy with recipients they were close with. They did, however, choose the direct question far more frequently with those with whom they had a professional and formal relationship (15 of 37) and occasionally the query preparatory ( 4 of 27 ) with this social distance group, suggesting a possible interaction between gender and social distance (when analyzing data from males). The results caution against broad generalizations about the interaction between directness and social distance. Instead, it may be that senders prefer particular, rather than all, direct strategies with recipients of a certain social distance and that they may mitigate direct requests more frequently than indirect requests.

\section{Request strategies according to status}

Table 9 shows the percentage of request strategies according to the recipients' status. Sixty-one head acts were directed to superiors, 39 to subordinates, 59 to peers at the same institution, 86 to peers at different institutions, 143 to clients, and 62 to vendors. Senders used direct strategies most frequently when writing to their superiors and least frequently when writing to their subordinates and peers at the same institution. This finding is striking, because it occurred even though $70.5 \%$ of the e-mails to superiors in the corpus were sent by females (who used more indirect strategies than males in general). Moreover, the recipients to whom the fewest direct requests were addressed (subordinates and peers at the same institution) were not the categories with the highest percentage of female senders (which were to superiors and clients), suggesting that gender was not a confounding variable.

This finding also occurred despite the fact that the smallest percentage of requests were for information, action, and continued correspondence, and the greatest percentage of requests were to superiors for permission, which suggests that request type was not likely a confounding variable. Nor was request type likely a confounding variable with peers at the same institution: senders directed the highest percentage of requests for action and lowest percentage of requests for meetings to them. However, it is possible that request type could have been a confounding variable with subordinates: senders directed the lowest percentage of requests for advice, confirmation, and permission, and the highest percentage of requests for meetings, to them.

This finding is even more striking because social distance did not appear to be a confounding variable. Although the greatest percentage of total direct requests was to superiors and to recipients with whom the sender had a professional and formal relationship, the greatest percentage of direct requests 
to superiors was to those with whom the sender had a professional relationship $(32.79 \%)$, twice the percentage of direct requests to those with whom the sender had a professional and formal relationship (16.39\%). Moreover, although the greatest percentage of total indirect requests was to subordinates and peers at the same institution and to recipients with whom the sender had a close relationship, the greatest percentage of indirect requests to subordinates was to those with whom the sender had a friendly but professional relationship and those whom the sender did not know (12.82\%, respectively). In fact, there was not a single indirect request to a subordinate with whom the sender had a close relationship. Similarly, the greatest percentage of indirect requests to peers at the same institution was to those with whom the sender had a professional relationship $(15.25 \%)$, more than twice the percentage of those with whom they had a close relationship (6.78\%).

A closer analysis of the data reveals that the presence of mitigating and intensifying features may be an equally important consideration when judging the directness of a request. Although senders used the greatest percentage of direct request strategies with superiors, they also mitigated requests to superiors most frequently $(70.49 \%$ containing mitigators only; $6.56 \%$ containing both mitigators and intensifiers). Requests least likely to be mitigated were directed to vendors (56.45\% containing mitigators only), followed by subordinates (58.97\% containing mitigators only). In terms of status, senders appeared to mitigate requests more frequently when addressing recipients to whom they wrote a greater percentage of direct requests. Thus, it would seem that the presence of mitigating and intensifying features, in addition to the request strategy chosen, may influence the directness of a request.

Regardless of the recipients' status, the imperative was the most frequent strategy senders used, especially with subordinates (41.03\%). The imperative was used least frequently with superiors $(26.23 \%)$. This finding again cautions against broad generalizations about the interaction between directness and status, given that senders used the greatest percentage of direct strategies and the fewest imperatives with superiors, and used the fewest direct strategies but the greatest percentage of imperatives with subordinates.

The smallest variety of request strategies was used with subordinates: two thirds of all requests to subordinates were made with either the imperative or the query preparatory strategy; the explicit performative, locution derivable, want statement, and expectation statement were never used with subordinates. In the case of clients, unlike that of any other status group, the percentage of direct questions exceeded that of query preparatory questions.

Need and expectation statements were much more popular when addressing superiors than with any other group, and need statements were just as common when addressing superiors as the query preparatory strategy was. This is partially surprising, given that need statements can sometimes appear very direct, as this example to a superior shows: "Long Term Care Insurance - need instructions with contact name at [insurance company name] 
to identify and evaluate my options." By contrast, expectation statements to superiors always used some form of "hope," which seemed polite, as this example from the dataset shows: "With that said, I was hoping that you or [first name] could speak with him in regards to the possibility of him having to travel at the end of the ag. season." However, these comparisons of need and expectation statements should be interpreted cautiously, given that these forms occurred infrequently in the dataset and the results for need statements could have been affected by gender, since females used a greater percentage of need statements than males did.

Table 9

Percentage of Request Strategies by Status

\begin{tabular}{|c|c|c|c|c|c|c|}
\hline Status & Superior & $\begin{array}{r}\text { Sub- } \\
\text { ordinate }\end{array}$ & $\begin{array}{l}\text { Peer at } \\
\text { the Same } \\
\text { Institution }\end{array}$ & $\begin{array}{l}\text { Peer at a } \\
\text { Different } \\
\text { Institution }\end{array}$ & Client & Vendor \\
\hline Imperative & 26.23 & 41.03 & 32.20 & 31.40 & 37.76 & 37.10 \\
\hline Elliptical & 4.92 & 5.13 & 0 & 2.33 & 6.99 & 3.23 \\
\hline $\begin{array}{l}\text { Explicit } \\
\text { performative }\end{array}$ & 6.56 & 0 & 0 & 5.81 & 2.80 & 1.61 \\
\hline $\begin{array}{l}\text { Hedged } \\
\text { performative }\end{array}$ & 6.56 & 2.56 & 3.39 & 1.16 & 0.70 & 4.84 \\
\hline Direct question & 8.20 & 10.26 & 16.95 & 8.14 & 15.38 & 14.52 \\
\hline $\begin{array}{l}\text { Locution } \\
\text { derivable }\end{array}$ & 0 & 0 & 3.39 & 2.33 & 0 & 0 \\
\hline Want statement & 6.56 & 0 & 5.08 & 10.47 & 5.59 & 4.84 \\
\hline Need statement & 11.48 & 2.56 & 0 & 5.81 & 1.40 & 1.61 \\
\hline Suggestory & 0 & 2.56 & 1.69 & 2.33 & 1.40 & 0 \\
\hline Expectation & 8.20 & 0 & 1.69 & 2.33 & 2.80 & 0 \\
\hline Total direct & 78.69 & 64.10 & 64.41 & 72.09 & 74.83 & 67.74 \\
\hline $\begin{array}{l}\text { Query } \\
\text { preparatory }\end{array}$ & 11.48 & 25.64 & 25.42 & 19.77 & 11.89 & 24.19 \\
\hline $\begin{array}{l}\text { Stating } \\
\text { preparatory }\end{array}$ & 6.56 & 7.69 & 6.78 & 5.81 & 9.09 & 4.84 \\
\hline Hint & 3.28 & 2.56 & 3.39 & 2.33 & 4.20 & 3.23 \\
\hline Total indirect & 21.31 & 35.90 & 35.59 & 27.91 & 25.17 & 32.26 \\
\hline
\end{tabular}


Query preparatory strategies were used more frequently when senders were writing to their peers, subordinates, and vendors than when they were writing to their superiors and clients. Although the number of e-mails written by females for each status group exceeded the number written by males, this finding is still surprising, because the percentage of e-mails written by females (who preferred the query preparatory and indirect strategies in general) was greatest when corresponding with superiors and clients. Had there been a strong interaction between gender and status, the greatest number of query preparatory strategies should have been used with superiors and clients. Moreover, other researchers (e.g., Chen, 2001) have found the query preparatory strategy to be the most predominant in student e-mails to their professors (which would seem to resemble the status difference between employees and their bosses), yet the percentage of query preparatory strategies with superiors was the lowest among all status groups, and senders used more than twice the percentage of query preparatory strategies with subordinates as they did with superiors.

In sum, the relationship between status and directness is complex: while direct strategies were used most frequently with superiors and least frequently with subordinates and peers at the same institution, the percentage of imperatives - the most direct strategy - was highest with subordinates and lowest with superiors, and the greatest percentage of mitigated head acts was directed to superiors, far more than the percentage of mitigated head acts directed to subordinates.

\section{Discussion}

The goal of the present study was to investigate the frequency of request strategies in e-mails written by native English-speaking professionals in the United States according to request category, gender, status, and social distance. Results from the corpus analysis showed that direct request strategies occurred at about two and one half times the rate of indirect strategies and were often mitigated by lexico-syntactic devices. Though direct strategies were also found to be more common than indirect strategies in native speakers' e-mails to faculty for lower imposition requests (Biesenbach-Lucas, 2007), conventionally indirect forms have been cited more frequently as the preferred strategy among native English-speaking students in both authentic e-mails and discourse completion tasks (e.g., Chen, 2001; Lee, 2004). Moreover, whereas the query preparatory has been cited as a preferred strategy in student e-mails to faculty (Chen, 2001), this strategy was not as commonly reflected in employees' e-mails to their superiors as it was to other status groups in this corpus. These findings may shed some light on how professionals write e-mail requests in the workplace, which seems to differ from how students write e-mails to faculty. 
Perhaps one of the most important findings in this study concerns the predominance of the imperative across all gender, status, and social distance groups. The prevalence of the imperative in the corpus is surprising, considering that other researchers (cf. Lee, 2004) have reported a very low percentage of the imperative in their dataset, although this may be due to differences between students' and professionals' e-mails or between authentic and discourse-completion data. A closer examination of the imperative in this dataset showed that it was frequently mitigated by politeness markers, thus suggesting that the politeness of a request cannot be judged solely by the request strategy chosen.

Senders' preferred request strategies did vary somewhat according to request category, gender, social distance, and status. The preferred strategies were the imperative for action, confirmation, and continued correspondence requests; the direct question for information and advice requests; and the query preparatory for meeting and permission requests. Males in this corpus used a greater percentage of direct strategies than females. Vine (2009) noted a similar tendency of males to be more direct: male managers in New Zealand used a larger percentage of the imperative than female managers to communicate directives. In this corpus, both males and females mitigated over $10 \%$ more requests when writing to recipients of the opposite sex. This might partially be explained by what O'Neill and Colley (2006) discovered about "same-sex camaraderie" in student e-mails to staff, in which both males and females adopted different communicative strategies to lower-status members of the same sex.

With respect to social distance, senders in this e-mail corpus adopted direct request strategies most frequently when writing recipients with whom they had a professional and formal relationship and least frequently with close recipients (in comparison to all social distance categories). In terms of status, senders adopted direct request strategies most frequently with superiors and least frequently with subordinates and peers at the same institution. These findings initially seemed to be counter to previous research that suggests that the greater the degree of social distance and the greater the status difference between interlocutors, the less direct the communication should be (Brown \& Levinson, 1987).

Yet the predominance of the most direct strategy - the imperativeshowed an opposite pattern in the dataset: fewer imperatives were used with superiors and with recipients in the "professional and formal" social distance category. With regard to gender, although males used the greatest percentage of direct strategies with males, they used the smallest percentage of imperatives with males. This finding is interesting because it reveals that senders did not choose the most direct strategy - the imperative-as often with recipients they wrote direct requests to most frequently, thus underscoring the importance of not forming gross generalizations about senders' preferences 
for direct or indirect strategies. It may be that senders prefer particular direct or indirect strategies over others with certain recipients.

Moreover, it may be that the politeness of a request is influenced not only by the level of directness of the strategy chosen, but also by the degree of mitigation. Direct strategies in the dataset, such as the imperative and want statement, were often mitigated. Interestingly, although senders used direct strategies most frequently with superiors, their e-mails to superiors were also most likely to be mitigated. Senders generated the greatest percentage of indirect requests to close recipients, yet they also were least likely to mitigate requests to close recipients. It could be that senders mitigate direct requests more frequently than they do indirect requests. Notably, Biesenbach-Lucas (2007) also observed that politeness features occurred more frequently with direct than indirect requests in native English-speaking graduate student e-mails to faculty.

Another variable that has been found to influence the length and formality of e-mail messages is intertextuality (cf. Evans, 2012), and this could have also had an impact on the sender's choice of request strategy in this dataset. Most of the request e-mails in this study were chain initiators (218), and another 98 reflected the first written correspondence about the topic after senders had discussed it. Sixty-one represented the second written correspondence about the topic, 59 reflected the third or greater written correspondence about the topic, and 14 included no response to this question. There was a slightly lesser percentage of direct request strategies among chain initiators $(68 \%)$ as compared to e-mails at other positions along the chain $(77 \%, 74 \%$, and $75 \%$, respectively), which may suggest that senders tend to adopt a less direct approach the first time a request is introduced. While the greatest percentage of direct request strategies occurred with emails representing the first written correspondence about a topic that had already been discussed $(77 \%)$, this category also included the smallest percentage of the imperative request strategy $(27 \%)$, as compared to $36 \%, 41 \%$, and $39 \%$ for the other categories. This again shows that the most direct request strategy - the imperative-occurred least frequently in the category to which senders wrote direct requests most frequently, which lends further support to the notion that senders may prefer particular request strategies over others with certain recipients and in certain contexts.

\section{Conclusion}

As the first study to investigate e-mail requests across industries in the North American workplace, this study offers useful findings for ESP instructors who have little evidence from authentic professional e-mails on which to base their instruction for preparing university or graduate students for writing emails in the North American workplace. Such instruction is particularly valuable for non-native English-speaking students who are preparing to enter a 
workforce in which e-mail is a predominant mode of communication and English is a predominant medium of communication.

When teaching professional e-mail composition, instructors may want to raise students' awareness about the request strategies that occur most frequently with different request goals and recipients, drawing attention to gender, social distance, and status differences in several authentic request e-mails. Instructors can design "noticing" tasks in which students learn when and how native speakers use particular request strategies and the most common mitigators, which in this dataset were the conditional clause, past tense, and politeness markers such as "please." Then, instructors can present students with a request e-mail composed by a non-native speaker and have them revise it to be more polite using these mitigating strategies. For example, if a non-native speaker has composed a request using a want statement with the present tense of the verb "want," students might revise it using a mitigator such as the past tense or the conditional to make the head act more polite. Instructors can invite students to explain their rhetorical choices and then present relevant research findings to augment the discussion (e.g., that no native speaker in the corpus had used an unmitigated form of "want" among all 27 want statements in the dataset). Instructors can then present students with a writing prompt for a professional e-mail request (which incorporates authentic information about audience and context drawn from survey data from a native English sender of a similar request e-mail). Before students write their e-mail, instructors can facilitate a discussion about how the request type, gender, status, and social distance could impact their communication, thereby underscoring the importance of similar audience variables echoed in Evans (2012). Students can then compose an e-mail and compare their rhetorical choices with those of the native speaker. The class would critique a range of models (written by their classmates and the native speaker), which is consistent with the approach advocated by BELF scholars that there be no single "perfect" model.

In a separate lesson, instructors may want to engage students in analyzing when particular request strategies, such as the imperative, direct question, or query preparatory, are appropriate and have them analyze several authentic e-mails to learn how native speakers politely formulate a request with these strategies. Such instruction is particularly valuable, because many researchers have found that non-native speakers use fewer mitigators than native speakers (e.g., Biesenbach-Lucas, 2007; Chen, 2001), are more likely to judge these direct requests as appropriate (Rinnert \& Iwai, 2010), and lack the intuitive awareness that native speakers have of register variation in e-mails (Giménez-Moreno, 2011). Instructors can have students classify the level of directness of a range of head acts extracted from professional e-mails and paraphrase those head acts in another polite and appropriate way for the audience and context. Instructors can share authentic examples and relevant research about the likelihood of native speakers using a particular request 
strategy or mitigator for the given context (e.g., native speakers often formulate requests for advice with an interrogative-either the direct question or query preparatory strategy). Instructors can conclude the lesson by inviting students to critique the effectiveness and politeness of their peers' paraphrases. Such lessons, which would provide students with authentic native speaker examples and engage them in explicit noticing and productive tasks, are modelled after successful approaches in teaching pragmatics (cf. BardoviHarlig \& Griffin, 2005) and could supplement or replace textbook instruction on e-mail composition that tends to be based upon the authors' intuition.

The purpose of this study was to analyze professional request e-mails from native English speakers in a variety of industries, so the findings would not be limited to a single institution or field. All e-mails in this study shared the same communicative purpose (Swales, 1990). However, because the e-mails were gathered from various discourse communities, it may be difficult to generalize the results beyond this corpus. While possible interactions among request strategy, request type, gender, social distance, and status were discussed, the size and composition of the corpus limited any statistical analysis to test the significance of the interaction. To offer a more comprehensive analysis of the request genre and adhere more closely to what Bhatia (2008) calls for in critical genre analysis, future studies might investigate the request perspective, supportive moves, and industry variation in request e-mail correspondence and the possible impact of the imposition of the request on the request strategy. It is hoped that the preliminary insights offered in this study will help narrow the gap researchers have identified between the academy and the workplace (Bhatia \& Bremner, 2012) and contribute to future research in this area.

\section{Acknowledgements}

I wish to thank Wayne Leopold and Danielle Pelletier for their tremendous help with developing and administering the survey and Kathleen Bailey, Renée Jourdenais, and Jean Turner for their valuable guidance with the research. I would like to extend my gratitude to the editor and anonymous reviewers of TESL Canada Journal for their insightful feedback, as well as my sincere thanks to all the participants who generously donated their time to complete the e-mail survey.

\section{The Author}

Lisa Leopold is Associate Professor of English for Academic and Professional Purposes at the Middlebury Institute of International Studies at Monterey, where she teaches business correspondence, editing, and public speaking to international graduate students. Her research interests include business English, content-based instruction, and role-play pedagogy.

\section{References}

Androutsopoulos, J. (2006). Introduction: Sociolinguistics and computer-mediated communication. Journal of Sociolinguistics, 10(4), 419-438.

Bardovi-Harlig, K., \& Griffin, R. (2005). L2 pragmatic awareness: Evidence from the ESL classroom. System, 33(3), 401-415.

Baron, N. S. (2000). Alphabet to e-mail: How written English evolved and where it's heading. New York, NY: Routledge. 
Beaufort, A. (2008). Writing in the professions. In C. Bazerman (Ed.), Handbook of research on writing: History, society, school, individual, text (pp. 221-235). New York, NY: Lawrence Erlbaum.

Bhatia, V. K. (2008). Genre analysis, ESP and professional practice. English for Specific Purposes, 27(2), 161-174.

Bhatia, V. K., \& Bremner, S. (2012). English for business communication. Language Teaching, 45(4), 410-445.

Biesenbach-Lucas, S. (2005). Communication topics and strategies in e-mail consultation: Comparison between American and international university students. Language Learning $\mathcal{E}$ Technology, 9(2), 24-46.

Biesenbach-Lucas, S. (2007). Students writing e-mails to faculty: An examination of e-politeness among native and non-native speakers of English. Language Learning \& Technology, 11(2), 59-81.

Biesenbach-Lucas, S., \& Weasenforth, D. (2000, September). "Please help me": L1/L2 variations in solicitations in electronic conferences. Paper presented at the 20th annual Second Language Research Forum (SLRF), Madison, WI.

Blum-Kulka, S. (1987). Indirectness and politeness in requests: Same or different? Journal of Pragmatics, 11(2), 131-146.

Blum-Kulka, S., Danet, B., \& Gherson, R. (1985). The language of requesting in Israeli society. In J. P. Forgas (Ed.), Language and social situations (pp. 113-139). New York, NY: Springer-Verlag.

Blum-Kulka, S., \& House, J. (1989). Cross-cultural and situational variation in requesting behavior. In S. Blum-Kulka, J. House, \& G. Kasper (Eds.), Cross-cultural pragmatics: Requests and apologies (pp. 123-154). Norwood, NJ: Ablex.

Blum-Kulka, S., House, J., \& Kasper, G. (1989). The CCSARP coding manual. In S. Blum-Kulka, J. House, \& G. Kasper (Eds.), Cross-cultural pragmatics: Requests and apologies (pp. 273-294). Norwood, NJ: Ablex.

Blum-Kulka, S., \& Olshtain, E. (1984). Requests and apologies: A cross-cultural study of speech act realization patterns (CCSARP). Applied Linguistics, 5(3), 196-213.

Blum-Kulka, S., \& Olshtain, E. (1986). Too many words: Length of utterance and pragmatic failure. Studies in Second Language Acquisition, 8(2), 165-179.

Bodman, J., \& Eisenstein, M. (1988). May God increase your bounty: The expression of gratitude in English by native and non-native speakers. Cross Currents, 15(1), 1-21.

Bremner, S. (2006). Politeness, power, and activity systems: Written requests and multiple audiences in an institutional setting. Written Communication, 23(4), 397-423.

Brown, P., \& Levinson, S. C. (1987). Politeness: Some universals in language usage. Cambridge, UK: Cambridge University Press.

Chen, C.-F. E. (2001, February). Making e-mail requests to professors: Taiwanese vs. American students. Paper presented at the annual meeting of the American Association for Applied Linguistics, St. Louis, MO.

Chen, C.-F. E. (2006). The development of e-mail literacy: From writing to peers to writing to authority figures. Language Learning \& Technology, 10(2), 35-55.

Crystal, D. (2001). Language and the Internet. New York, NY: Cambridge University Press.

Ehrenreich, S. (2010). English as a business lingua franca in a German multinational corporation: Meeting the challenge. International Journal of Business Communication, $47(4), 408-431$.

Ellis, R. (1992). Learning to communicate in the classroom: A study of two language learners' requests. Studies in Second Language Acquisition, 14(1), 1-23.

Evans, S. (2012). Designing e-mail tasks for the Business English classroom: Implications from a study of Hong Kong's key industries. English for Specific Purposes, 31(3), 202-212.

Evans, S. (2013). Perspectives on the use of English as a business lingua franca in Hong Kong. International Journal of Business Communication, 50(3), 227-252.

Fordyce, K., \& Fukazawa, S. (2004). Interlanguage pragmatics: Syntactic and lexical downgrading in request realization by Japanese EFL learners. Hiroshima Journal of School Education, 10, 237-246. 
Gains, J. (1999). Electronic mail-A new style of communication or just a new medium?: An investigation into the text features of e-mail. English for Specific Purposes, 18(1), 81-101.

Gimenez, J. C. (2000). Business e-mail communication: Some emerging tendencies in register. English for Specific Purposes, 19(3), 237-251.

Gimenez, J. (2006). Embedded business e-mails: Meeting new demands in international business communication. English for Specific Purposes, 25(2), 154-172.

Giménez-Moreno, R. (2011). Register variation in electronic business correspondence. International Journal of English Studies, 11(1), 15-34.

Hartford, B. S., \& Bardovi-Harlig, K. (1996). "At your earliest convenience": A study of written student requests to faculty. In L. F. Bouton (Ed.), Pragmatics and language learning (Monograph series Vol. 7, pp. 55-69). Urbana, IL: DEIL.

Hassall, T. (2001). Modifying requests in a second language. International Review of Applied Linguistics in Language Teaching, 39(4), 259-283.

Hewitt, P. (2006). Electronic mail and internal communication: A three-factor model. Corporate Communications: An International Journal, 11(1), 78-92.

Ho, V. (2010). Constructing identities through request e-mail discourse. Journal of Pragmatics, $42(8), 2253-2261$.

House, J., \& Kasper, G. (1987). Interlanguage pragmatics: Requesting in a foreign language. In W. Lörscher \& R. Schulze (Eds.), Perspectives on language in performance (pp. 1250-1288). Tübingen, Germany: Gunter Narr.

Kankaanranta, A., \& Louhiala-Salminen, L. (2010). “English? -Oh, it's just work!": A study of BELF users' perceptions. English for Specific Purposes, 29(3), 204-209.

Kankaanranta, A., \& Planken, B. (2010). BELF competence as business knowledge of internationally operating business professionals. International Journal of Business Communication, 47(4), 380-407.

Kessler, G. (2010). Virtual business: An Enron e-mail corpus study. Journal of Pragmatics, 42(1), 262-270.

Kling, R. (1996). Social relationships in electronic forums: Hangouts, salons, workplaces, and communities. In R. Kling (Ed.), Computerization and controversy: Value conflicts and social choices (2nd ed., pp. 426-454). San Diego, CA: Academic Press.

Lee, C. (2004). Request strategy and second language acquisition. In Current perspectives and future directions in foreign language teaching and learning: Proceedings of the CLaSIC 2004 Conference. Singapore: Centre for Language Studies, National University of Singapore.

Mackey, D. (2004). Send me a message: A step-by-step approach to business and professional writing. New York, NY: McGraw Hill.

Nelson, G. L., Carson, J., Al Batal, M., \& El Bakary, W. (2002). Cross-cultural pragmatics: Strategy use in Egyptian Arabic and American English refusals. Applied Linguistics, 23(2), 163-189.

O'Neill, R., \& Colley, A. (2006). Gender and status effects in student e-mails to staff. Journal of Computer Assisted Learning, 22(5), 360-367.

Poncini, G. (2004). Discursive strategies in multicultural business meetings. Bern, Switzerland: Peter Lang.

Radicati Group, Inc. (2015). Email market, 2015-2019 [Executive summary]. Retrieved from http:// www.radicati.com/wp/wp-content/uploads/2015/07/Email-Market-2015-2019-ExecutiveSummary.pdf

Rinnert, C., \& Iwai, C. (2010). I want you to help me: Learning to soften English requests. In D. H. Tatsuki \& N. R. Houck (Eds.), Pragmatics: Teaching speech acts (pp. 29-46). Alexandria, VA: TESOL.

Rogerson-Revell, P. (2007). Using English for international business: A European case study. English for Specific Purposes, 26(1), 103-120.

Schmidt, T. Y. (1994). Authenticity in ESL: A study of requests (Master's thesis). Southern Illinois University, IL.

Searle, J. R. (1976). A classification of illocutionary acts. Language in Society, 5(1), 1-23. 
Swales, J. (1990). Genre analysis: English in academic and research settings. New York, NY: Cambridge University Press.

Tatton, H. (2008). “Could you, perhaps, pretty please?": Request directness in cross-cultural speech act realization. Working Papers in TESOL and Applied Linguistics, 8(2), 1-4.

Van Nus, M. (1999). Business genres and their corporate context. Document Design, 1(3), 187-197.

Vine, B. (2009). Directives at work: Exploring the contextual complexity of workplace directives. Journal of Pragmatics, 41(7), 1395-1405.

Wolfson, N. (1989). Perspectives: Sociolinguistics and TESOL. Rowley, MA: Newbury House.

Wolfson, N., Marmor, T., \& Jones, S. (1989). Problems in the comparison of speech acts across cultures. In S. Blum-Kulka, J. House, \& G. Kasper (Eds.), Cross-cultural pragmatics: Requests and apologies (pp. 174-196). Norwood, NJ: Ablex. 